The silicon, manganese, and phosphorus in the hot metal oxidize rapidly, forming a hot fluid slag, free of foam, which runs quickly out of the flush hole. The ore has no tendency to float in the slag or to be carried out of the furnace with the flush. The use of the same ore as a feed ore also speeds up carbon reduction and is three times as effective as previously used feed ores.

Heat charged with the Liberian ore took metal with less reaction, minimizing slag spills and floor congestion. Tons per hour operating performance shows an increase of 1 to 1.5 tons per $\mathrm{hr}$ for the shop using heats charged with the imported ore. Charge ore, feed ore, and limestone consumption were considerably less.

It is believed that the Liberian ore more closely approaches the ideal charge and feed ore than any other used in the industry today. Liberian ore outperformed Brazilian ore tested previously. It produced the highest production rates and yields, the lowest bottom and bank delays, the best melt carbon control, and higher average roof life, using the least amount of ore, limestone, and fuel. Finally, the first shipment was used without practical limits on the percentage of iron in the charge in fear of blowing or spills.

\title{
Moroccan Ore
}

\author{
by C. C. Benton
}

$\mathbf{F}$ AMILIARIZATION with differences in shop conditions throughout the industry is necessary for evaluation of results obtained from the use of any particular ore for charge oxide, which in the case considered here is Moroccan ore. The average hot metal analysis at the Fairchild steel works in 1951, prior to the use of import ore, was 0.85 pct silicon, 0.25 pct manganese, 0.81 pct phosphorus, and 0.048 pct sulphur. Because of this analysis, 235 to $240 \mathrm{lb}$ of limestone per ton of ingots were charged.

Approximately 30 pct of all heats were made with flush slag practice. Limestone reduction is impossible with flush slag practice and thus a minimum of 60 pct hot metal is required to obtain flush. Seventy percent of all heats tapped are maximum 0.10 pct carbon, with the majority 0.08 pet maximum carbon.

Moroccan ore first was used as a charge at Fairfield in April 1951. From April 1951 through January 1952, 2054 heats ore were tapped. The size of Moroccan ore is good with 26 pct above 3 in., 41 pct from 1 to $3 \mathrm{in}$. and only 10 pct below $0.25 \mathrm{in}$. The moisture content is approximately 2.7 pct. Physical characteristics of Moroccan ore are compared with those of Brazilian ore in Table I.

The reaction on metal addition is vigorous with quick rise and fast flush. Flush begins from 5 to 13 min after metal addition and finishes in approximately $30 \mathrm{~min}$. No foaming or excessive blowing has been experienced.

Iron loss is greater than that of Brazilian ore but less than occurs with iron ore sinter. The ingot yield on Moroccan ore has been 87.22 pct.

The chemical analysis of Moroccan ore is good except for the high sulphur content. Sulphur pickup from the ore charged averaged 0.005 pct with no difficulty in meeting sulphur specification except when using a high sulphur fuel for melting. Chemical analyses of Moroccan and Brazilian ores and iron sinter are given in Table II.

C. C. BENTON is Assistant Superintendent, Open Hearth Dept., Fairfield Steel Works, Tennessee Coal \& Iron Div., U. S. Steel Co. This poper was presented at the National Open Hearth Steel Conference, AIME, Pittsburgh, Apr. 1, 1952.
Table I. Screen Analysis of Moroccan Ore, Pct

\begin{tabular}{|c|c|c|}
\hline Screen Size & Moroccan Ore & Brazilian Ore \\
\hline \multirow[t]{2}{*}{$\begin{array}{l}+3 \mathrm{in} . \\
-3+21 / 2 \mathrm{in} . \\
-21 / 2+11 / 2 \text { in. } \\
-11 / 2+1 \mathrm{in} . \\
-1+5 / 8 \text { in. } \\
-5 / 8+1 / 4 \text { in. } \\
-1 / 4+3 / 16 \mathrm{in} . \\
-3 / 16+10 \mathrm{mesh} \\
-10+20 \mathrm{mesh} \\
-20+40 \mathrm{mesh} \\
-40+60 \mathrm{mesh} \\
-60+80 \mathrm{mesh} \\
-80+100 \mathrm{mesh} \\
-100 \mathrm{mesh}\end{array}$} & $\begin{array}{r}26.1 \\
10.0 \\
20.9 \\
10.4 \\
11.2 \\
11.4 \\
1.7 \\
2.2 \\
1.3 \\
1.6 \\
0.8 \\
0.5 \\
0.2 \\
1.7\end{array}$ & $\begin{array}{r}30.3 \\
2.7 \\
4.9 \\
8.7 \\
8.5 \\
8.6 \\
11.5 \\
2.8 \\
5.8 \\
4.5 \\
0.1 \\
5.8 \\
1.2 \\
4.6\end{array}$ \\
\hline & 100.0 & 100.0 \\
\hline
\end{tabular}

Table II. Chemical Analysis of Moroccan Ore, Pct

\begin{tabular}{lccc}
\hline & $\begin{array}{c}\text { Moroccan } \\
\text { Ore }\end{array}$ & $\begin{array}{c}\text { Iron } \\
\text { Sinter }\end{array}$ & $\begin{array}{c}\text { Brazilian } \\
\text { Ore }\end{array}$ \\
\hline Metallic iron & 63.74 & 67.93 & 68.49 \\
Silica & 3.53 & 1.98 & 0.43 \\
Alumina & 0.67 & 0.17 & 0.51 \\
Lime & 0.98 & & \\
Magnesium & 0.44 & 0.04 & 0.07 \\
Manganese & 0.21 & 0.093 & 0.036 \\
Sulphur & 0.226 & 0.006 & \\
Phosphorus & 0.028 & 0.111 & \\
Copper & 0.036 & & \\
\hline
\end{tabular}

Table III. Comparison of Heats Using Moroccan Ore with Other Charge Oxides

\begin{tabular}{lrrr}
\hline & $\begin{array}{c}\text { Moroccan } \\
\text { Ore }\end{array}$ & $\begin{array}{c}\text { Iron } \\
\text { Sinter }\end{array}$ & \multicolumn{1}{c}{$\begin{array}{c}\text { Brazilian } \\
\text { Ore }\end{array}$} \\
\hline Tons per heat & 189.77 & 190.13 & 190.50 \\
Time of heats, tap to tap & $10: 41$ & $10: 59$ & $10: 33$ \\
Time of heats, charge to tap & $9: 29$ & $9: 47$ & $9: 21$ \\
Tap per tap, tons per hr & 17.86 & 17.31 & 18.06 \\
Charge per tap, tons per hr & $\mathbf{2 0 . 0 2}$ & 19.44 & $\mathbf{2 0 . 3 6}$ \\
Charge oxide per ton ingots, lb & 177 & 188 & 160 \\
Feed oxide per ton ingots, lb & 54 & 67 & 60 \\
\hline
\end{tabular}

From studies on use of various charge ores, considerable sulphur is removed on flush. Results of the heats show Moroccan ore can be used in combination with low sulphur fuels with advantage to production. Table III compares heats using Moroccan ore and heats using other charge oxides. 